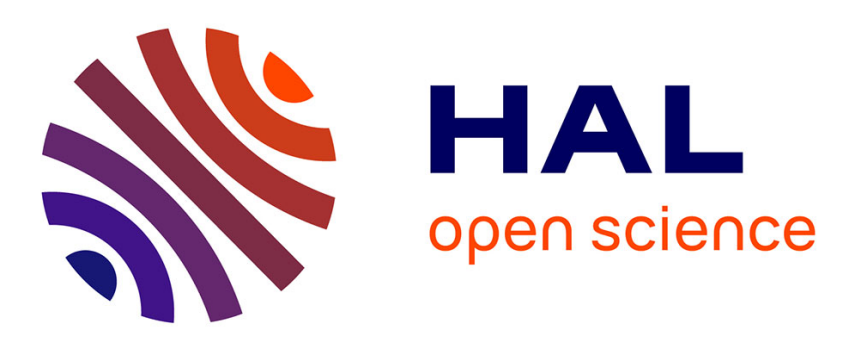

\title{
Using Fuel cell as a Power Supply for Superconducting Coil
}

\author{
Melika Hinaje, Kévin Berger, Jean Lévêque, Bernard Davat
}

\section{To cite this version:}

Melika Hinaje, Kévin Berger, Jean Lévêque, Bernard Davat. Using Fuel cell as a Power Supply for Superconducting Coil. IEEE Transactions on Applied Superconductivity, 2014, 24 (6), pp.4701906. 10.1109/TASC.2014.2316200 . hal-00981955v2

\section{HAL Id: hal-00981955 https://hal.science/hal-00981955v2}

Submitted on 23 Apr 2014

HAL is a multi-disciplinary open access archive for the deposit and dissemination of scientific research documents, whether they are published or not. The documents may come from teaching and research institutions in France or abroad, or from public or private research centers.
L'archive ouverte pluridisciplinaire HAL, est destinée au dépôt et à la diffusion de documents scientifiques de niveau recherche, publiés ou non, émanant des établissements d'enseignement et de recherche français ou étrangers, des laboratoires publics ou privés. 


\title{
Using Fuel cell as a Power Supply for Superconducting Coil
}

\author{
M. Hinaje, K. Berger, J. Lévêque and B. Davat,Member, IEEE
}

\begin{abstract}
Fuel cells are electrochemical energy converters which allow transformation of the chemical energy of a fuel to electricity through oxido-reduction reaction. The voltage of an elementary cell is usually near $1 \mathrm{~V}$ in open circuit and around 0.6 $V$ in nominal conditions of power generation. Fuel cells are then by essence low voltage sources, so that for most practical applications, power management is carried out by electronic converters, allowing in particular to rise the voltage to usual application levels.

In this paper, we propose to take advantage of this low voltage for a specific application such as superconducting coils power supply. The solution proposed here for the generation of the perfectly direct current relies upon a fuel cell fed by hydrogen. The main advantages to be taken from fuel cells operated at very low voltages are autonomy - no supply connected on the grid, ensured continuous operation, together with the electrical quality of the current generated, i.e. free.
\end{abstract}

Index Terms-Current control, Power supply, Proton exchange membrane Fuel cell, Superconducting coil.

\section{INTRODUCTION}

$\mathrm{T}$ he first demonstration of fuel cell (FC) was conducted by Sir William Grove in 1839 [1]. The research on fuel cell was very active in 1960 where fuel cells were developed for the NASA's space program. Technology at that time let the Alkaline Fuel Cell (AFC) be the best choice of electrical source on the space shuttle. The first Proton Exchange Membrane Fuel Cell (PEMFC) was developed during this program. The breakthrough of DuPont on Nafion ${ }^{\circledR}$ membrane in late of 1960 made the PEMFC more suitable for real world application [2]. The research on fuel cells has been increased rapidly since 1997 by the awareness of the energy and environmental problems. Various types of fuel cell are

This work was supported by ICÉEL Carnot institute for Energy and Environment in Lorraine.

M. Hinaje is with the Resarch Group on Electrical Engineering, University of Lorraine, TSA 60 604, 54518 Vandoeuvre cedex, France. (e-mail: melika.hinaje@univ-lorraine.fr).

$\mathrm{K}$. Berger is with the Resarch Group on Electrical Engineering, University of Lorraine, BP 70239, 54506 Vandoeuvre-lès-Nancy cedex, France. (e-mail: kevin.berger@univ-lorraine.fr).

J. Lévêque is with the Resarch Group on Electrical Engineering, University of Lorraine, BP 70239, 54506 Vandoeuvre-lès-Nancy cedex, France. (e-mail: jean.leveque@univ-lorraine.fr).

B. Davat is with the Resarch Group on Electrical Engineering, University of Lorraine, TSA 60604,54518 Vandoeuvre cedex, France. (e-mail: bernard.davat@univ-lorraine.fr). available, but PEMFC seems to be the most practical among the low temperature types. The application of the PEMFC range from small portable devices to stationary power supplies for resident or industrial use [3, 4].

Fuel cells are by essence low DC voltage sources, so that for most practical applications, power management is carried out by electronic converters, allowing in particular to rise the voltage to usual application levels.

Besides fuel cells are not suitable when sudden variations of current are needed, principally because of the fairly slow response of the gas flow rate controllers. This slow dynamics results in the necessity to associate a buffer component e.g. batteries or supercapacitors, whose function is to deal with transient energy demands and to allow a reversible operation as well (fuel cells are usually not reversible energy converters).

In this paper, we propose to take advantage of the natural low voltage character of the fuel cell to supply superconducting coils.

First of all, PEMFC will be introduced together with the so called fuel cell system. Then, a potential application of fuel cell as controlled current source for superconducting coils will be highlighted. Finally, some prospects will be given.

Potential applications are:

- Embedded systems propulsion, where the power generation is made by a fuel cell and a superconducting motor. Prospective studies are made in this direction for automotive applications and should be extended to naval and aerospace sectors [5], [6].

- When the supply current of a superconducting coil is very high (several $\mathrm{kA}$ ), a fuel cell can be more compact and simple to control. Usually, the fuel cell power density is about $600 \mathrm{~W} / \mathrm{kg}$ [7] comparing to classical power supply made with transformer and power electronics [8].

\section{INTRODUCING THE PROTON EXCHANGE MEMBRANE FUEL CELL}

What makes PEM fuel cell interesting among others is the use of hydrogen as fuel. Since, hydrogen is a gas that can be created from water by electrolysis process; there is no risk of shortage. The electrolysis process consists in passing an electric current through the water which will be decomposed into oxygen and hydrogen gases. The PEMFC operating is 
based on the reverse process. As long as reactants are supplied to electrodes, the fuel cell can feed the load.

\section{A. Operating principle}

Membrane fuel cells consist of two electrode compartments separated by a polymer electrolyte membrane preventing from the transport of gases and electrons. The two electrodes are lying on the each side of the membrane, forming the Membrane-Electrode Assembly (MEA) of the individual cell, as presented in Fig. 1. Protons generated by hydrogen oxidation (1) migrate with water towards the cathode through the membrane - which exhibits most often a high affinity to water - to the cathode, and take part in oxygen reduction (2) to water. Fuel cells can be characterized by the variation of the available voltage with the delivered current density as shown in Fig. 2.

$$
\begin{aligned}
& \mathrm{H}_{2} \rightarrow 2 \mathrm{H}^{+}+2 \mathrm{e}^{-} \\
& \frac{1}{2} \mathrm{O}_{2}+2 \mathrm{H}^{+}+2 \mathrm{e}^{-} \rightarrow \mathrm{H}_{2} \mathrm{O}
\end{aligned}
$$

The basic fuel cell reaction (oxidation and reduction) can be related to the resulting fuel cell current, $\mathrm{I}_{\mathrm{FC}}$, through Faraday law (3)-(5).2 moles of electrons are exchanged for the oxidation of 1 mole of hydrogen (3) and for 1 mole of produced water (5), as well as 4 moles of electrons for the oxygen reduction (4).

The consumption of reactants (molar flux, $\mathrm{N}_{\mathrm{i}, \text { cons }}$ ) increases in proportion with the fuel cell current, $\mathrm{I}_{\mathrm{FC}}$, as well as with the number of cells, $\mathrm{N}_{\text {cell }}$, in the stack. The same applies for water production resulting from redox reaction.

$$
\begin{aligned}
& \mathrm{N}_{\mathrm{H}_{2}, \text { cons }}=\zeta_{\mathrm{a}} \mathrm{N}_{\text {cell }} \frac{\mathrm{I}_{\mathrm{FC}}}{2 \mathrm{~F}} \\
& \mathrm{~N}_{\mathrm{O}_{2}, \text { cons }}=\zeta_{\mathrm{c}} \mathrm{N}_{\text {cell }} \frac{\mathrm{I}_{\mathrm{FC}}}{4 \mathrm{~F}} \\
& \mathrm{~N}_{\mathrm{H}_{2} \mathrm{O}, \text { prod }}=\mathrm{N}_{\text {cell }} \frac{\mathrm{I}_{\mathrm{FC}}}{2 \mathrm{~F}}
\end{aligned}
$$

Where $\mathrm{F}=9.65 .10^{4} \mathrm{C} / \mathrm{mol}$ is the constant Faraday. $\zeta_{\mathrm{a}}$, and $\zeta_{c}$ are the stoichiometric coefficients at anode and cathode side, respectively. Most of time, fuel cell are overfed $\left(\zeta_{\mathrm{a}}>1\right.$, $\left.\zeta_{c}>1\right)$ in order to compensate the pressure drop and to allow a good repartition of the reactant all over the catalyst layers.

Typical voltage of a cell at $0.5-0.6 \mathrm{~A} . \mathrm{cm}^{-2}$ is of the order of $0.6 \mathrm{~V}$. Higher voltages can be obtained in fuel cell systems by connecting multiple cells in series which form the fuel cell stack. The maximum fuel cell current depends on the active area of a fuel cell electrode that is to say the area is able to produce electricity from the supplied fuel. Increasing the active area can raise the maximum current rating. For instance, assume that the whole MEA area of a $100 \mathrm{~cm}^{2}$ PEMFC is active; it means that the fuel cell can reach about $50 \mathrm{~A}$.
The cell voltage $\mathrm{V}_{\mathrm{FC}}$ is the result of Open Circuit Voltage

\begin{tabular}{|c|c|c|}
\hline Symbol & Quantity & Units \\
\hline $\mathrm{d}$ & Flow rate & $\mathrm{L} / \mathrm{min}$ \\
\hline $\mathrm{F}$ & Constant Faraday & $\mathrm{C} / \mathrm{mol}$ \\
\hline I & Current & A \\
\hline $\mathrm{J}$ & Current density & $\mathrm{A} / \mathrm{m}^{2}$ \\
\hline $\mathrm{N}$ & Molar flux & $\mathrm{mol} / \mathrm{m}^{2}$ \\
\hline $\mathrm{N}_{\text {cell }}$ & Number of cell & - \\
\hline $\mathrm{P}$ & Pressure & $\mathrm{Pa}$ \\
\hline OCV & Open circuit voltage & $\mathrm{V}$ \\
\hline $\mathrm{R}$ & Ideal gas constant & $\mathrm{J} / \mathrm{mol} / \mathrm{K}$ \\
\hline $\mathrm{V}$ & Voltage & V \\
\hline $\mathrm{T}$ & Temperature & $\mathrm{K}$ \\
\hline$\eta$ & Voltage drop & $\mathrm{V}$ \\
\hline$\zeta$ & Stoichiometric coefficient & - \\
\hline \multicolumn{3}{|c|}{ Subscripts } \\
\hline 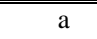 & & anode \\
\hline act & & activation \\
\hline $\mathrm{c}$ & & cathode \\
\hline cons & & consumption \\
\hline conc & & concentration \\
\hline $\mathrm{FC}$ & & Fuel cell \\
\hline $\mathrm{m}$ & & membrane \\
\hline 0 & & Normal conditions \\
\hline ohm & & ohmic \\
\hline prod & & production \\
\hline
\end{tabular}
(OCV) subtracted by the losses due to irreversibilities.

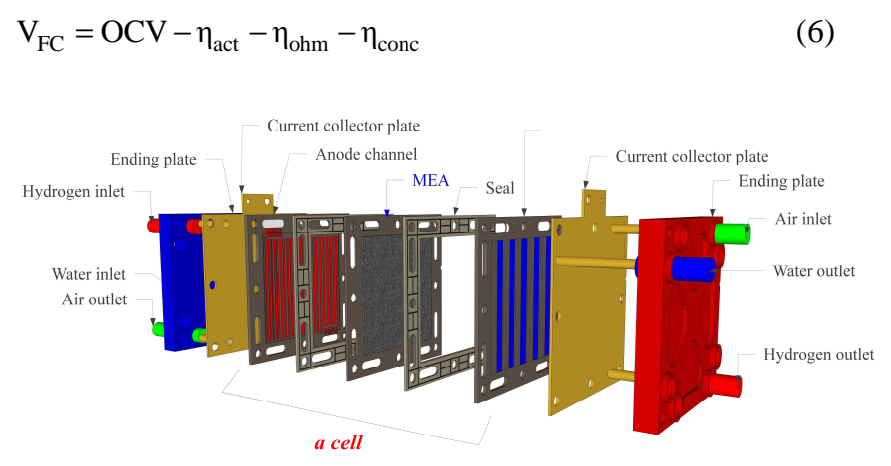

Figure 1.Sketch of a PEM single fuel cell cooled by water.

TABLE I NOMENCLATURE

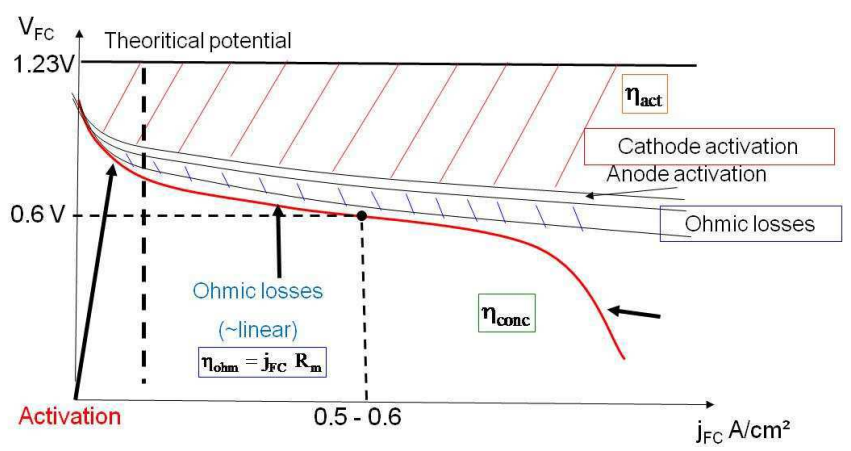

Figure 2. Single fuel cell polarization curve. 
A voltage proportion is lost in driving the chemical reaction that transfers the electrons. This voltage drop also called activation overvoltage is denoted $\eta_{\text {act }}$. As shown in Fig. 2, the activation overvoltage is highly non-linear. Activation losses are caused by the slowness of the reactions taking place on the surface of the electrodes.

The straight part located in the middle of the curve corresponds to ohmic losses, $\eta_{\mathrm{m}}$, and are mainly due to the membrane resistance, $\mathrm{R}_{\mathrm{m}}$. However, it has to be underlined that the membrane resistance depends on the fuel cell current, it is linked to the proton conductivity of the membrane.

Concentration losses, $\eta_{\text {conc }}$, become significant at high current when the slow rate of the reactants transport is unable to meet the high demanded current. This voltage drop is caused by the slow rate of mass transport (diffusion limitation) that leads to the depletion of reactants in the vicinity of active reaction sites and the overaccumulation of reactants product which prevent the reactants from reaching the reactant sites.

\section{B. Fuel cell system}

Figure 3 presents an example of a fuel cell system fed by dry hydrogen from cylinder and humidified air. Set point of reactant flow rates are imposed by means of Flow Controllers (FC). There are normally closed electromagnetic valves at each gas inlet that ensure the shutdown of reactant supply in case of default and normally open valves at the outlets. Condensers can be used to collect water coming from unconsumed gases. In some fuel cell system, to avoid waste, unconsumed hydrogen is recovered and fed back to inlet. However, in doing so, the system is not only more expensive but also more complex. There is also an alternative in the regulation of fuel cell temperature, in some other systems; fuel cells are cooled by air.

The reactant flow rate is set according to (7)

$$
\left\{\begin{array}{l}
\mathrm{d}_{\mathrm{H}_{2}}=\mathrm{N}_{\text {cell }} \frac{\mathrm{I}_{\mathrm{ref}}}{2 \mathrm{~F}} \cdot \frac{\mathrm{RT}_{0}}{\mathrm{P}_{0}} \cdot \zeta_{\mathrm{a}} \cdot 1000 \cdot 60 \\
\mathrm{~d}_{\text {air }}=\mathrm{N}_{\text {cell }} \frac{\mathrm{I}_{\mathrm{ref}}}{4 \mathrm{~F}} \cdot \frac{\mathrm{RT}_{0}}{\mathrm{P}_{0}} \cdot \frac{1}{0.21} \cdot \zeta_{\mathrm{c}} \cdot 1000 \cdot 60
\end{array}\right.
$$

Where $\mathrm{N}_{\text {cell }}$ is the number of cells of the stack, $I_{\text {ref }}$ the demanded fuel cell current and $\zeta_{\mathrm{a}}, \zeta_{\mathrm{c}}$ the anode and cathode stoichiometric coefficients respectively $\mathrm{T}_{0}=273.16 \mathrm{~K}$ and $\mathrm{P}_{0}=1.013 \cdot 10^{5} \mathrm{~Pa}$.

The fuel cell performance depends on several operating parameters such as fuel cell temperature, supply gas (or stoichiometric coefficients), relative humidity and operating pressure.

Some experimental results presented in Fig. 4 to Fig. 6 point out the influence of operating conditions on single fuel cell performances.

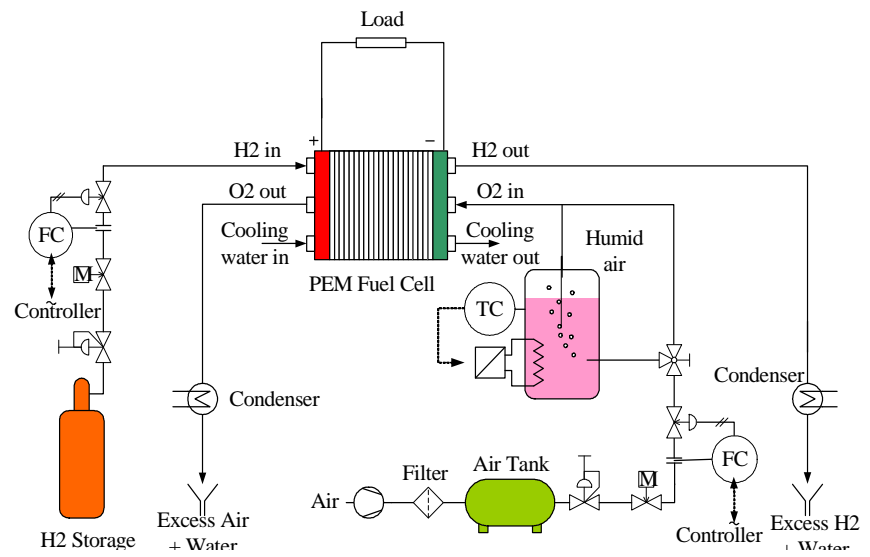

Figure 3.PEM fuel cell system.

\section{Influence of operating conditions}

1) Influence of reactant flow rates

The experiment was led on the single fuel cell fed by humidified air and dry hydrogen from cylinders. The fuel cell is cooled by water and its active area is $100 \mathrm{~cm}^{2}$.

As it can be seen in Fig. 4, the decrease of hydrogen flow rate does not make any difference on the fuel cell voltage. On the contrary, as air flow rate decreases, the fuel cell voltage decreases until air supply becomes insufficient $\left(\zeta_{c}=1.1\right)$ for the demanded current which leads to a strong drop of the voltage (Fig. 5)

This phenomenon is called air starvation. Since the fuel cell is not overfed, air does not reach the entire active region and the reduction reaction does not occur uniformly in the cell [9].

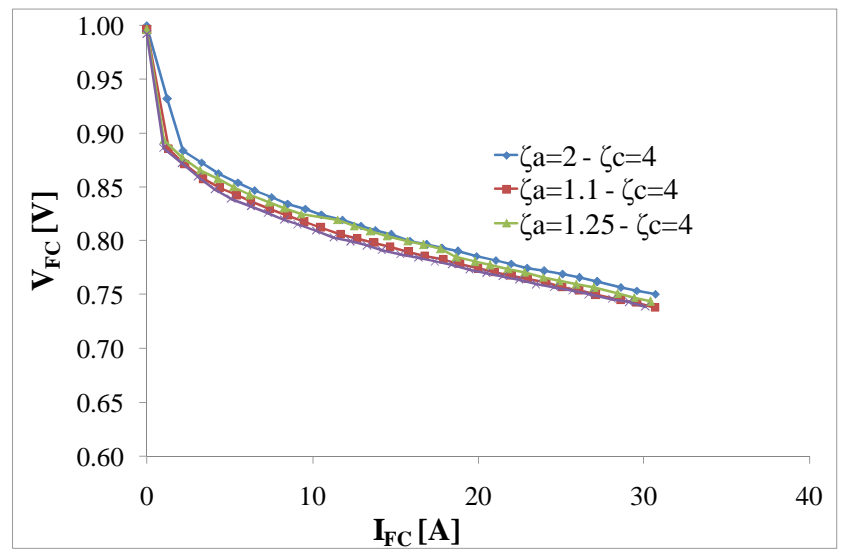

Figure 4.Single fuel cell polarization curves versus hydrogen flow rate. 
2) Humidification and Fuel cell temperature

Among the losses, a significant portion comes from the membrane resistance. Its value depends on the water content of the membrane and the temperature. As it can be seen in Fig. 6 , the conductivity is improved as the membrane is well humidified (and heated) [10-15]. Since the membrane is humidified using the air supply, air starvation leads also to the decrease of humidification and thus to voltage drop.

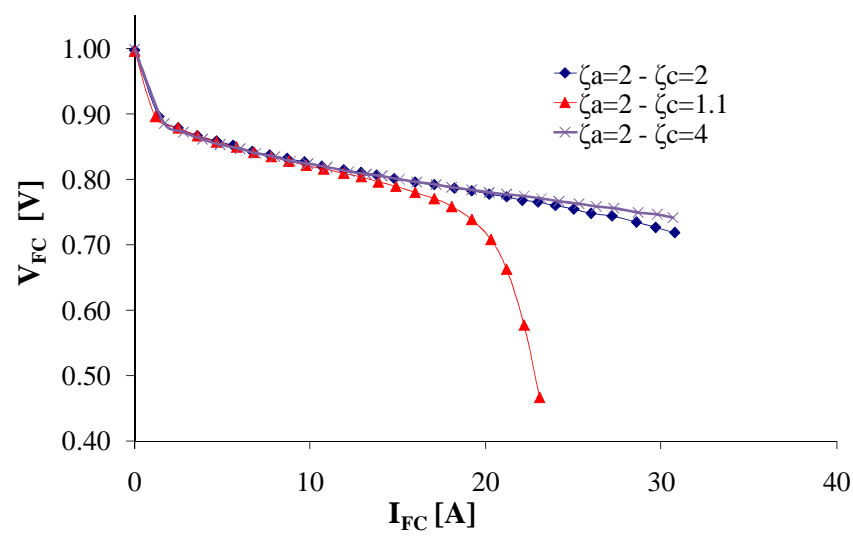

Figure 5.Single fuel cell polarization curves versus air flow rate.

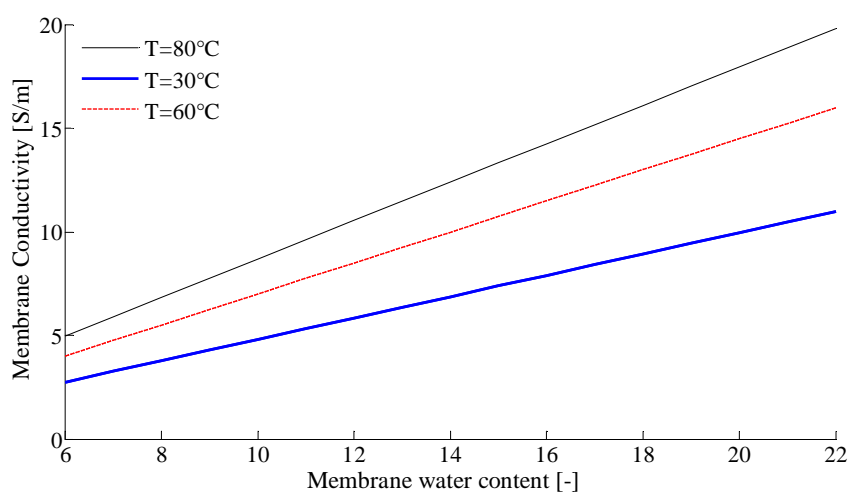

Figure 6.Variation of membrane conductivity according to temperature and water content.

\section{FUEL CELL OPERATING AS A CONTROLLED CURRENT SOURCE}

\section{A. Fuel cell current controlled by hydrogen flow rate}

In a previous paper [16], it has been highlighted the potential use of a single PEM fuel cell as a current source controlled by hydrogen flow rate $\left(\zeta_{\mathrm{a}}=1\right)$ through $\mathrm{I}_{\text {ref }}(7)$. In this case, the single fuel cell is short-circuited and runs in the operating conditions given in Table II. As the fuel cell voltage is near zero, the fuel cell operating point is located in the last part of the polarization curve that is to say in diffusion limitation zone.

Figure 7 presents the time variation of hydrogen flow rate (Ch.3) and the fuel cell current (Ch.1) and voltage (Ch.2). A setpoint step of the hydrogen flow rate from $\mathrm{I}_{\mathrm{ref}}=20 \mathrm{~A}$ to $\mathrm{I}_{\mathrm{ref}}=$ 40 A leads to a fuel cell current step from $20 \mathrm{~A}$ to $40 \mathrm{~A}$. This new current rating is maintained since the hydrogen flow rate is regulated around $\mathrm{I}_{\mathrm{ref}}=20 \mathrm{~A}$. Then, the current is decreased

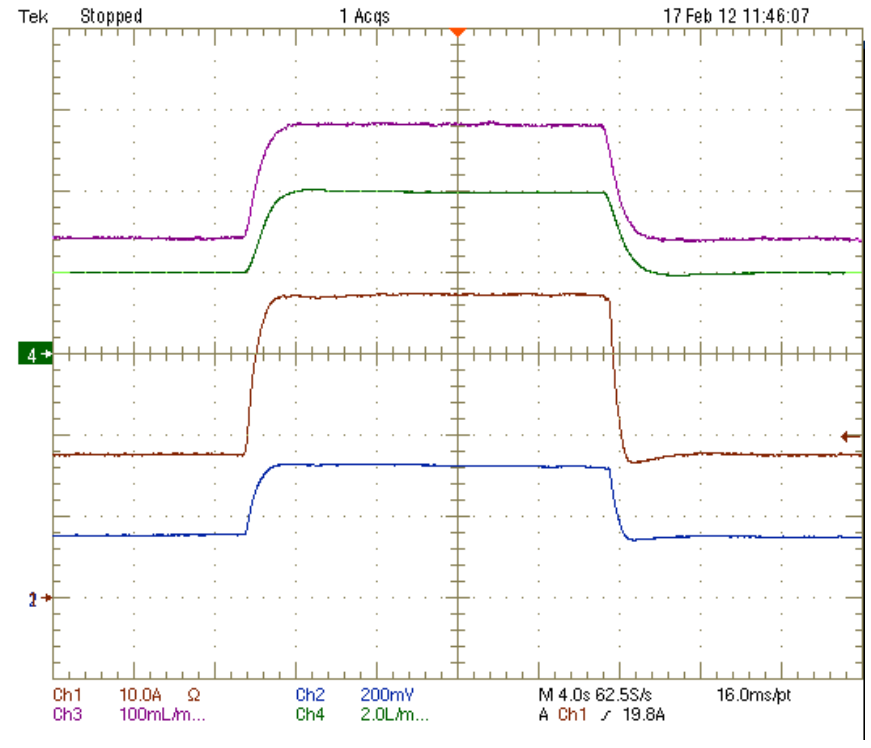

Figure 7. Demonstration of the current controlled by hydrogen flow rate $\left(I_{\text {ref }}=20 \mathrm{~A}-40 \mathrm{~A}-20 \mathrm{~A}\right)(\mathrm{Ch}$. 1. Fuel cell current, Ch. 2. Fuel cell voltage, Ch. 3. $\mathrm{H}_{2}$ flow rate, $\mathrm{Ch}$. 4. air flow rate).

down to $20 \mathrm{~A}$ by decreasing the reference current, i.e., hydrogen

As it can be seen, the transient response is quite slow; this is mainly due to hydrogen flow controller, its regulation has to be improved. However, in the case of superconducting applications, it is not detrimental.

\section{B. Operation condition setting}

We have proved that the fuel cell is able to run as a current source controlled by hydrogen flow rate. Now, we connect the fuel cell to a superconducting coil whose characteristics are given in Table III.

Some experiments have been firstly conducted to set the optimum operating condition of the single fuel cell as current source. Hence, polarization curves were plotted for different values of air relative humidity and fuel cell temperature (Table III and Fig. 8).

Setting the reference current at $10 \mathrm{~A}$ and anode stoichiometric coefficient, $\zeta_{\mathrm{a}}$, at 1 means that the fuel cell current cannot exceed 10A. However, as some fuel does not reach the catalyst sites and is not consumed, the reached current is slightly lower than 10 A, Fig. 8.

To run as a controlled current source, the fuel cell voltage has to tend to zero, the best operating conditions, in this case, are to fed the fuel cell by dry air under $40^{\circ} \mathrm{C}$.

\section{SUPPLY OF A SUPERCONDUCTING COIL}

\section{A. Test bench}

The test bench is composed of a single fuel cell system as presented in Fig. 3. Usually, air is humidified by means of a bubble which is not very convenient when regulation is needed. Instead, a CEM-system (Controlled Evaporation and Mixing) is used. The single fuel cell is a proton exchange membrane fuel cell of $100 \mathrm{~cm}^{2}$ active area manufactured by 
UBZM (Germany) connected to a superconducting coil (Table III and Fig. 10). This coil has already been characterized in the liquid nitrogen by an improved method [17].

There are flow controllers (FC) at each side of the fuel cell. The set point flow rates are imposed by means of a "real time" electronic card (dSPACE ${ }^{\circledR}$ DS1 104 card) used in combination with Matlab-Simulink ${ }^{\circledR}$ software according to (7).

TABLE II FUEL CELL OPERATING CONDITIONS

\begin{tabular}{clc}
\hline \hline Symbol & \multicolumn{1}{c}{ Quantity } & Value \\
\hline$\zeta_{\mathrm{a}}$ & Anode stoichiometric coefficient(7) & 1 \\
$\zeta_{\mathrm{c}}$ & Cathode stoichiometric coefficient (7) & 6 \\
$I_{r e f}$ & Reference current (7) & $20 \mathrm{~A}-40 \mathrm{~A}$ \\
$T$ & Fuel cell temperature & $40^{\circ} \mathrm{C}$ \\
$R H_{a}$ & Anode relative humidity & $0 \%$ \\
$R H_{c}$ & Cathode relative humidity & $65 \%$ \\
$\mathrm{P}_{\mathrm{a}}$ & Anode pressure & $1 \mathrm{~atm}$ \\
$P_{c}$ & Cathode pressure & $1 \mathrm{~atm}$ \\
\hline \hline
\end{tabular}

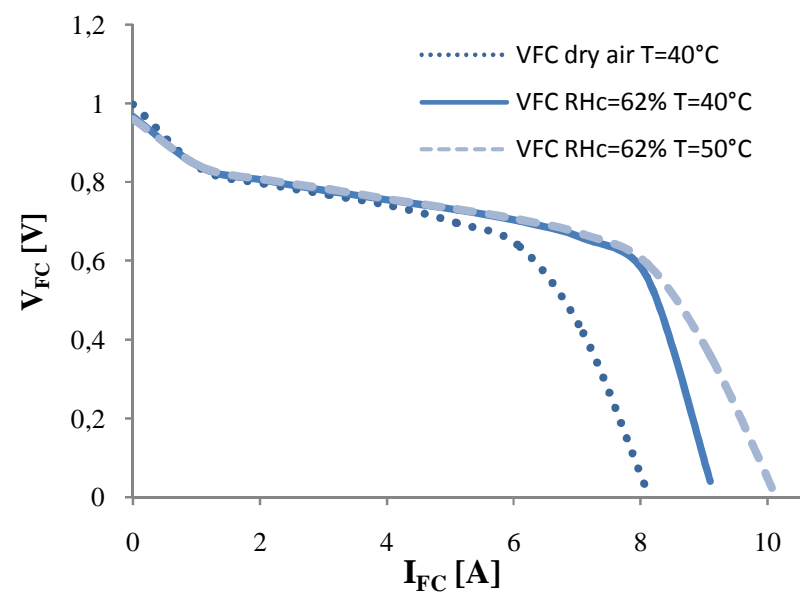

Figure 8.Polarization curves while varying the temperature and the relative humidity of inlet air.

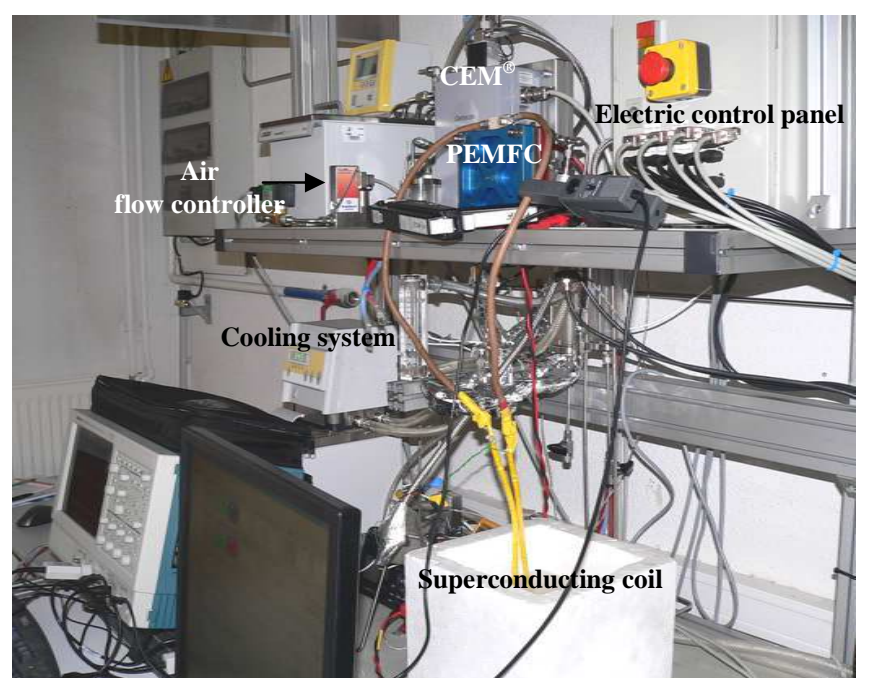

Figure 9.Test bench of a single PEM fuel cell connected to a superconducting coil cooled by liquid nitrogen.
TABLE III CHARACTERISTICS OF THE COIL AND THE WIRE

\begin{tabular}{cc}
\hline \hline Parameters & Value \\
\hline Thickness of the wire & $0.2 \mathrm{~mm}$ \\
Width of the wire & $4.0 \mathrm{~mm}$ \\
Critical current of the wire & 42 A@77 K and self field \\
Number of turn of the coil & 208 \\
External diameter of coil & $115 \mathrm{~mm}$ \\
Internal diameter of the coil & $60 \mathrm{~mm}$ \\
Inductance of the coil & $4 \mathrm{mH}$ \\
Critical current of the coil & $18 \mathrm{~A} @ 77 \mathrm{~K}$ \\
\hline \hline
\end{tabular}
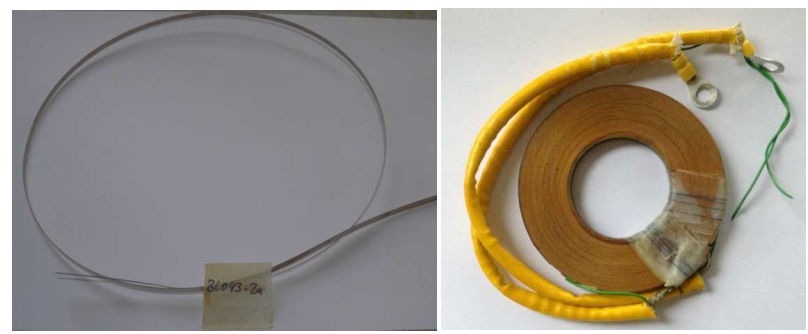

Figure 10.Sample of superconducting wire (BSCCO2212) and superconducting coil used in the experiment (on the right side)

\section{B. Experimental results}

Figure 11 presents the voltage-current curve of the superconducting coil when supplied by either a specific power supply for superconducting coil (American Magnetics [18]) or by the single PEM fuel cell. The same results are obtained which confirms the capability of the fuel cell to operate as a current source. The fuel cell voltage is about $100 \mathrm{mV}$ at $20 \mathrm{~A}$ (Fig. 12). This high value (compared to $10 \mathrm{mV}$ of the superconducting coil), is due to the resistance of the wire, estimated to $4 \mathrm{~m} \Omega$. This shows the importance of wires choice when using the fuel cell as a current source.

Figure 13 presents the current profile, set through hydrogen flow rate by decreasing the reference current from 20 A down to $5 \mathrm{~A}$ by step of $5 \mathrm{~A}$. A step command of the hydrogen flow rate from $I_{\text {ref }}=15$ A down to $I_{\text {ref }}=20$ A leads to a fuel cell current step from $15 \mathrm{~A}$ up to $20 \mathrm{~A}$. This new current rating remains constant since the hydrogen flow rate is regulated around $I_{\text {ref }}=20 \mathrm{~A}$. Because of the time constant of the hydrogen flow controller, the transient response is quite slow; its regulation has still to be improved.

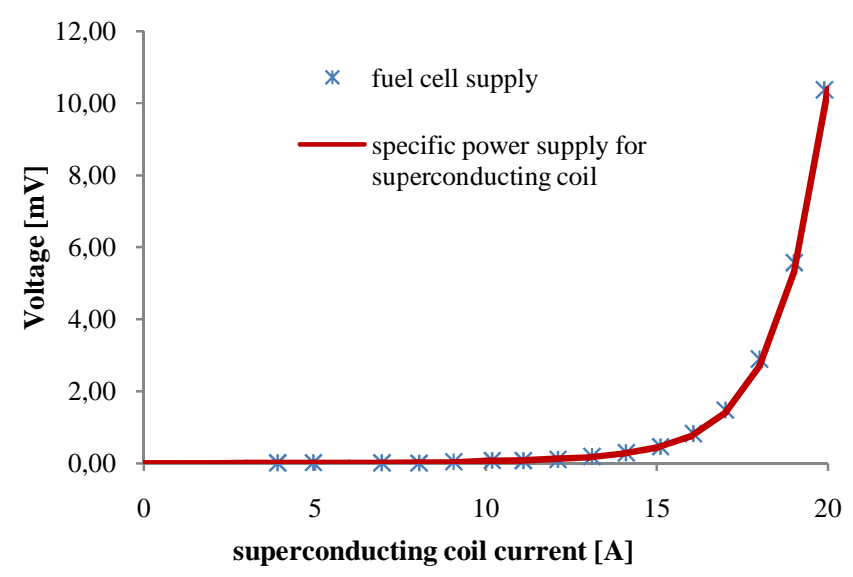

Figure 11.Superconducting coil characterization using single PEM fuel cell. 


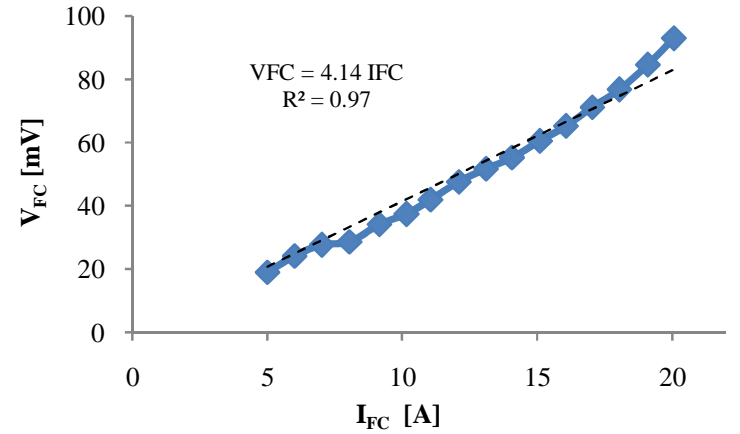

Figure 12.Fuel cell voltage versus current during the superconducting coil supply.

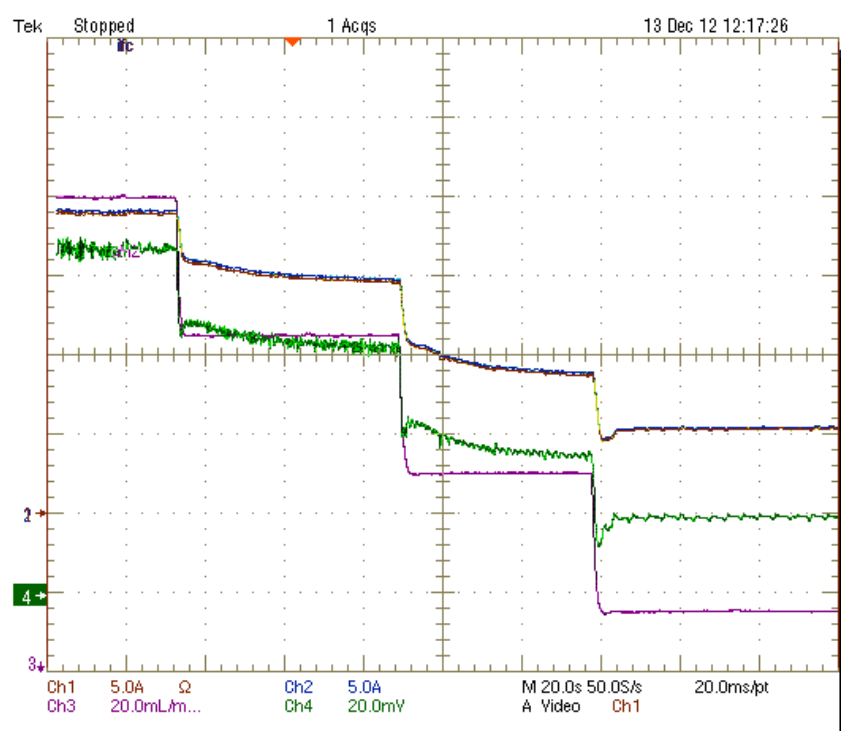

Figure 13.Demonstration of the current controlled by hydrogen flow rate $\left(I_{\text {ref }}=20-15-10-5 A\right)$ (Ch. 2. Fuel cell current, Ch. 3. $\mathrm{H}_{2}$ flow rate, Ch. 4. Fuel cell voltage).

\section{CONCLUSION}

In this paper, a new supply for superconducting coil has been presented. Taking benefit of the natural low voltage of single fuel cell and of the possibility to control its current by means of the hydrogen flow rate, a superconducting coil has been characterized. Although the fuel cell system transient response is quite slow, it is suitable to superconducting coil.

This particular application of PEM fuel cell requires operating well below the threshold voltage close to shortcircuit, thus a study on the alteration of the fuel cell lifetime must be carried out. Examination of the current density distribution appears necessary to assess the feasibility of the technique. Additional experiments have also to be done by supplying a more inductive superconducting coil at higher current and fuel cell current ripple has to be estimated.

\section{REFERENCES}

[1] J. Larminie and A. Dicks, Fuel Cell Systems Explained, 2nd ed. NJ: John Wiley \& Sons, 2003.

[2] T. Matsuura, Polymer Membranes for Fuel Cells. New York: Springer Science + Business, 2009
[3] G. Mauro, et al., "Hydrogen-Based Technologies for Mobile Applications," in Renewable Resources and Renewable Energy: CRC Press, 2006, pp. 225-272.

[4] K.-A. Adamson, Stationary Fuel Cells: An Overview, 1st ed. Oxford: Elsevier, 2007.

[5] Oyama H., Shintato T., Hayashi K., Kitajima K., Ariyoshi A. and Sawai T., " Application of Superconductors for Automobiles", SEI Technical Review, N 67, October 2008.

[6] Masson P., Breschi M., Tixador P., Luongo C., " Design of HTS Axial Flux Motor for Aircraft Propulsion", IEEE Transactions on Applied Superconductivity, Vol. 17, N. 2, June 2007,pp. 1533-1536.

[7] Basu S., Recent trends in Fuel Cell Science and Technology, Springer, 2007.

[8] Rummel Th., Mönnich Th., Köppen M., Harmeyer E., "Final tests of the power supply system for the W7-X superconducting magnet system", Fusion Engineering and Design, vol. 84, pp. 1658-1661,June 2009.

[9] Shen Q. et. Al., "The voltage characteristics of proton exchange membrane fuel cell (PEMFC) under steady and transient states", Journal of Power Sources 179 (2008) 292-296.

[10] Springer T. E., Zawodzinski T. A., Wilson M. S and Gottesfeld S., "Characterization of Polymer Electrolyte Fuel Cells Using AC Impedance Spectroscopy", J. Electrochem. Soc., Vol. 143, pp. 587-599, 1996.

[11] Hinatsu J. T., Mizuata M. and Takenaka H., "water uptake of perfluorosulfonic acid membrane from liquid and water and water vapor", J. Electrochem. Soc, vol 141, pp. 1493-1498, 1994.

[12] Chiang M.-S., and Chu H.-S., "Numerical investigation of transport component design effect on proton exchange membrane fuel cell", Journal of Power Sources, vol 160, pp. 340-352, 2006.

[13] Liu F., lu G., and Wang C.-Y., "Water transport coefficient distribution through the membrane in polymer electrolyte fuel cell", J. Membrane Science, vol. 287,pp. 126-131, 2007.

[14] X. Ye, C. Y. Wang, "Measurements of water transport propertiesthrough membrane electrode assemblies. Part I membranes", J. Electrochem. Soc., B676-B682, 2007.

[15] Fuller T. F. and Newman J., "Water and thermal management in solidpolymer-electrolyte fuel cells," J. Electrochem. Soc., vol. 140, pp. 12181225, 1993.

[16] Hinaje M., Raël S., Caron J.-P., Davat B., An innovating application of PEM fuel cell: Current source controlled by hydrogen supply. International Journal of Hydrogen Energy, September 2012; 37 (17):12481-88.

[17] Leclerc J., Berger K., Douine B., Lévêque J., "Enhancement of the E(J, B) Power Law Characterization for Superconducting Wires from Electrical Measurements on a Coil", IEEE Transactions on Applied Superconductivity, vol. 22 (3), 6400504, June 2012.

[18] http://www.americanmagnetics.com

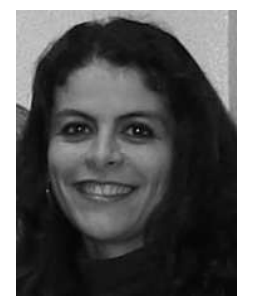

Melika Hinaje was born in Nancy, France, in 1978. She received the M.S. degree in electrical engineering from the University of Nancy, Nancy, France in 2002, and the Ph.D. degree from the National Polytechnic Institute of Lorraine (INPL), Nancy, France, in 2005. Since 2006, she has been an Assistant Professor at National Polytechnic Institute of Lorraine, Nancy, France. Her research activities in the department of electrical engineering (Groupe de Recherche en Electrotechnique et Electronique de Nancy concern fuel cells. she has defended her Habilitation qualification (accreditation to supervise research) in june 2012.

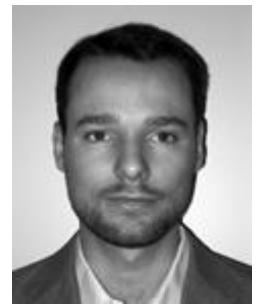

Kévin Berger received the Ph.D. degree in electrical engineering from the Université Henri Poincaré, Nancy, France, in 2006. From 2006 to 2008, he joined the Grenoble Electrical Engineering Laboratory (G2Elab) and the Néel Institut, Grenoble, as a postdoctoral researcher in order to work on superconductor modeling using FLUX® software and a HTS conduction-cooled SMES. Since 2010, he has been an Assistant Professor at the University of Lorraine, Nancy, France. His research interests deal with the design and modeling of superconducting devices like cryomagnets 
while taking into account coupled magneto-thermal behavior. His research topics also include electrical characterization of superconducting material and AC loss measurements.

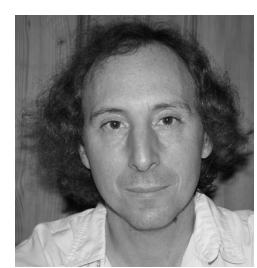

Jean Lévêque was born in Angers, France, in 1963.

$\mathrm{He}$ received his $\mathrm{Ph}$. D. in electrical engineering from University of Grenoble, France, in 1993.

$\mathrm{He}$ is currently Professor at the University of Nancy. As member of the Groupe de Recherche en Electrotechnique et Electronique de Nancy, his main subjects of research concern characterization and modelization of superconducting material and applications.

Bernard. Davat (M'89) received the Engineer degree from the Ecole Nationale Supérieure d'Electrotechnique, d'Electronique, d'Informatique, d'Hydraulique et des Télécommunications (ENSEEIHT), Toulouse, France, in 1975, the $\mathrm{Ph} . \mathrm{D}$. degree in electrical engineering from the Institut National Polytechnique de Toulouse (INPT) in 1979, and the "Docteur d'Etat" degree from the INPT in 1984. From 1980 to 1988, he was a

Researcher at the French National Center for Scientific Research (CNRS). Since 1988, he has been a Professor at the Institut National Polytechnique de Lorraine (INPL), Nancy, France. He is the author of Power Semiconductor Converters. His current research interests include power electronic structures, drives, and electrochemical devices (fuel cells, batteries, supercapacitors) 